\title{
Differential activity of innate defense antimicrobial peptides against Nocardia species
}

\author{
Siegbert Rieg ${ }^{1 *}$, Benjamin Meier ${ }^{1}$, Eva Fähnrich ${ }^{1}$, Anja Huth', Dirk Wagner ${ }^{1}$, Winfried V Kern', Hubert Kalbacher ${ }^{2}$
}

\begin{abstract}
Background: Members of the genus Nocardia are ubiquitous environmental saprophytes capable to cause human pulmonary, disseminated and cutaneous nocardiosis or bovine mastitis. Innate immunity appears to play an important role in early defense against Nocardia species. To elucidate the contribution of antimicrobial peptides (AMPs) in innate defense against Nocardia, the activity of human $\alpha$-defensins human neutrophil peptides (HNPs) 13 , human $\beta$-defensin (hBD)-3 and cathelicidin LL-37 as well as bovine $\beta$-defensins lingual and tracheal antimicrobial peptides (LAP, TAP) and bovine neutrophil-derived indolicidin against four important Nocardia species was investigated.

Results: Whereas N. farcinica ATCC 3318 and N. nova ATCC 33726 were found to be susceptible to all investigated human and bovine AMPs, N. asteroides ATCC 19247 was killed exclusively by neutrophil-derived human $\alpha$-defensins HNP 1-3 and bovine indolicidin. N. brasiliensis ATCC 19296 was found to exhibit complete resistance to investigated human AMPs and to be susceptible only to bovine indolicidin.

Conclusion: Selected AMPs are capable to contribute to the first line of defense against Nocardia, yet, susceptibility appears to vary across different Nocardia species. Obtained results of neutrophil-derived AMPs to possess the broadest antinocardial spectrum are remarkable, since nocardiosis is characterized by a neutrophil-rich infiltrate in vivo.
\end{abstract}

\section{Background}

Nocardia represent a genus of aerobic actinomycetes and belong specifically to the family Mycobacteriaceae [1]. Nocardia are aerobic, gram-positive, filamentous, branching rods and can be found as ubiquitous environmental saprophytes in soil, dust, organic matter and water. Due to recent advances in phenotypic and molecular characterization (especially $16 \mathrm{~S}$ rRNA gene sequencing) the spectrum of Nocardia has expanded, with more than 30 species described [2]. At least 13 Nocardia species have been implicated in human infection with varying geographic prevalence throughout the world [3].

Human infections usually arise from inhalation or direct inoculation into skin or soft tissue structures. Major forms of Nocardia infection are pulmonary nocardiosis, disseminated and CNS nocardiosis, cutaneous/lymphocutaneous nocardiosis and mycetoma. Nocardiosis may be considered as opportunistic

\footnotetext{
*Correspondence: siegbert.rieg@uniklinik-freiburg.de

${ }^{1}$ Center for Infectious Diseases \& Travel Medicine, University Medical Center, Hugstetter Strasse 55, 79106 Freiburg, Germany
}

infection with chronic lung disease (often in association with long-term corticosteroid treatment), transplantation, malignancies, diabetes mellitus and alcohol abuse as most prevalent underlying conditions [4]. Nevertheless, a review of more than 1000 cases of Nocardia infection revealed no identifiable predisposing immunocompromising factors in approximately $30 \%$ of patients [5]. Additionally, Nocardia are well-recognized pathogens in animals with bovine masititis representing the most important infection.

The characteristic histopathological feature of nocardiosis consisting of an acute pyogenic inflammatory reaction i.e. a predominant neutrophil-rich infiltrate as well as results of prior studies point towards an important role of innate defense mechanism against Nocardia species.

Antimicrobial peptides (AMPs) represent evolutionarily conserved multifunctional molecules of innate immunity. In mammals, AMPs like human $\beta$-defensins (hBD) 1-3 and bovine lingual or tracheal antimicrobial peptide (LAP, TAP) are expressed by cells within the 
epithelial lining or are delivered to sites of infection by circulating leukocytes [6-8]. Examples of the latter group of AMPs include human neutrophil peptides (HNPs) 1-3, bovine indolicidin or human cathelicidin LL-37 [9-11]. AMPs are produced constitutively or are induced upon infection or inflammation and exert activity against a broad spectrum of microorganisms including gram-positive and gram-negative bacteria, enveloped viruses, protozoa and fungi [12]. Apart from a direct microbicidal effect, AMPs exhibit a variety of additional functions by promoting chemotaxis and phagocytosis, stimulating angiogenesis and wound healing or neutralizing LPS effects [13].

There is increasing evidence that AMPs take part in innate defense against Nocardia-related bacteria such as Mycobacterium tuberculosis [14] or Actinomyces israelii and naeslundii [15]. The aim of the current study was to elucidate the contribution of AMPs in innate immunity against different Nocardia species. We therefore investigated the activity of several important epithelialand neutrophil-derived human and bovine AMPs against the four nocardial species $N$. farcinica, $N$. nova, $N$. asteroides and $N$. brasiliensis, all of whichrepresent major human and bovine pathogens.

\section{Results and Discussion}

Levofloxacin was used as killing control to compare antinocardial potency of tested AMPs and showed dosedependent activity against all four nocardial strains. The peptide DPY without antimicrobial activity served as negative control and exhibited no activity against all tested Nocardia strains (data not shown).

\section{Activity of human AMPs against Nocardia species}

All tested human AMPs exhibited activity against $N$. farcinica ATCC 3318 (Figure 1A) and N. nova ATCC 33726 (Figure 1B). Human $\beta$-defensin hBD-3 revealed strongest activity with $\mathrm{LD}_{90}$ of $16 \mu \mathrm{g} / \mathrm{ml}$ against both strains.
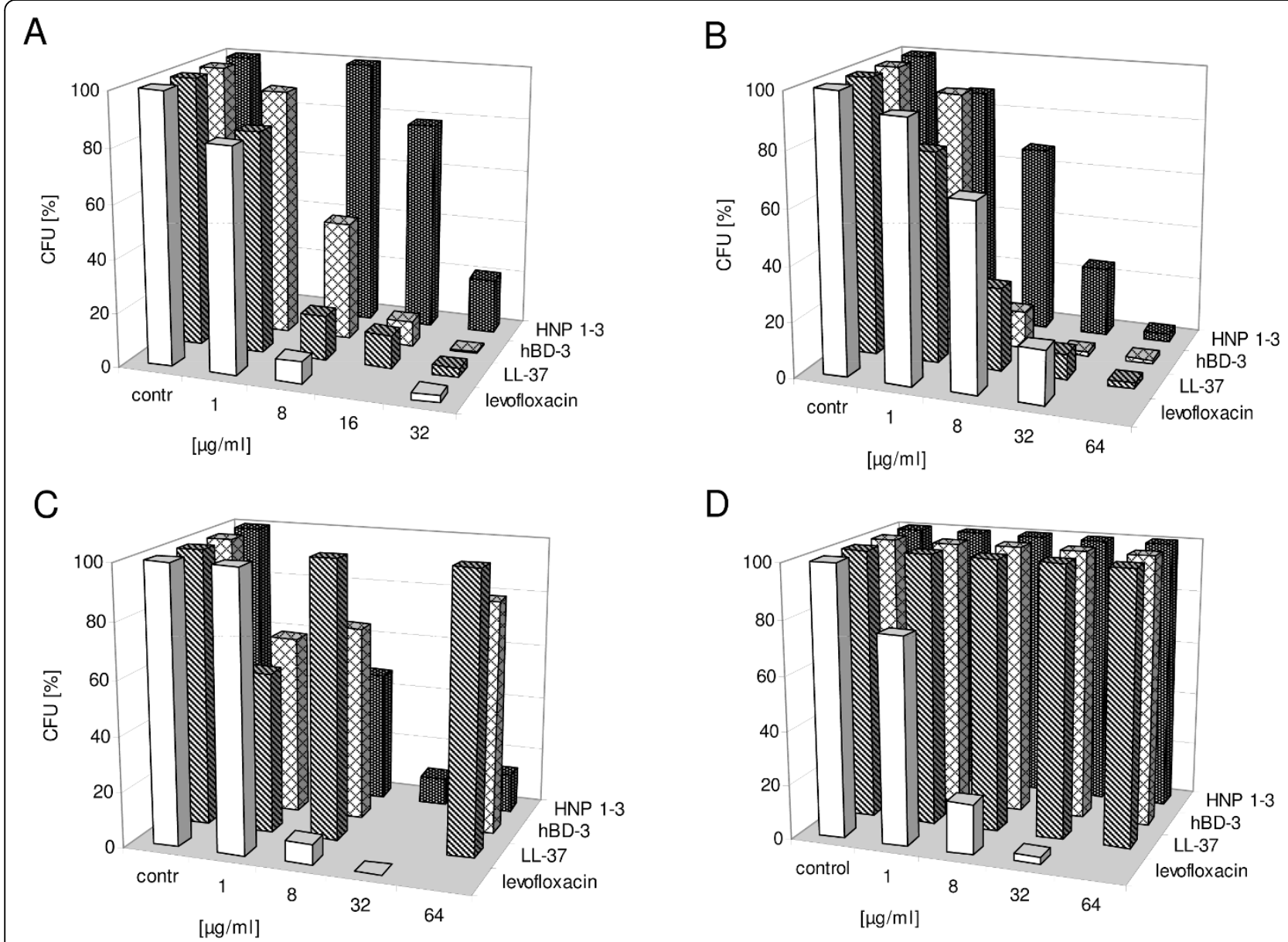

Figure 1 Activity of human AMPs HNP 1-3, hBD-3, LL-37 and levofloxacin (killing control) against A N. farcinca ATCC 3318 (p < 0.05 for all tested substances), B N. nova ATCC 33726 ( $p<0.05$ for all tested substances), C N. asteroides ATCC 19247 (levofloxacin $p<0.05$, HNP1-3 $p=$ 0.11 ) and D N. brasiliensis ATCC 19296 (levofloxacin $p<0.05$ ) was investigated using a colony forming unit (CFU) assay. Data are means (percent CFU reduction) of at least four independent sets of experiments with each peptide and each Nocardia species. 
Human cathelicidin LL-37 showed $\mathrm{LD}_{90}$ of $32 \mu \mathrm{g} / \mathrm{ml}$ respectively. Accordingly, we found human $\alpha$-defensins HNP 1-3 to be active, although higher concentrations were needed with $\mathrm{LD}_{90}>32 \mu \mathrm{g} / \mathrm{ml}$ against $N$. farcinica and $\mathrm{LD}_{90}$ of $64 \mu \mathrm{g} / \mathrm{ml}$ against $N$. nova (Table 1). Notably, hBD-3 and LL-37 were found to be more potent against $N$. nova than levofloxacin in equivalent concentrations.

To address additive or synergistic effects of AMPs, we performed a model assay using $N$. farcinica and a combination of LL-37 and HNP 1-3 (Figure 2). Since the combination of the two AMPs exhibited nocardial killing comparable to each peptide alone at twofold higher concentrations, we found additive activity of the two AMPs.

In contrast to results with $N$. farcinica and $N$. nova, hBD-3 and LL-37 did not show antinocardial activity against $N$. asteroides ATCC 19247 (Figure 1C). Only human $\alpha$-defensins HNP 1-3 were found to be active against $N$. asteroides with $\mathrm{LD}_{90}$ of $32 \mu \mathrm{g} / \mathrm{ml}$.

N. brasiliensis ATCC 19296 proved to be resistant to all human AMPs tested since neither HNP 1-3 nor hBD-3 or LL-37 exhibited killing activity in concentrations up to $64 \mu \mathrm{g} / \mathrm{ml}$ (Figure 1D). Remarkably, stronger growth of $N$. brasiliensis was observed with all three AMPs investigated. Enhanced growth was not found after incubation with equivalent concentrations of DPY (data not shown). To investigate whether proteolytic degradation of AMPs by $N$. brasiliensis-derived proteases might play a role, we added a protease inhibitor mix during incubation in CFU assays. Protease inhibitors were not able to alter the observed AMP resistance of $N$. brasiliensis, yet enhanced growth of $N$. brasiliensis after co-incubation with protease inhibitors could be observed again(data not shown).

\section{Activity of bovine AMPs against Nocardia species}

CFU-assays revealed activity of all tested bovine AMPs against N. farcinica ATCC 3318 (Figure 3A). Neutrophil-derived indolicidin and bovine $\beta$-defensin LAP showed potent killing with $\mathrm{LD}_{90}$ of $16 \mu \mathrm{g} / \mathrm{ml}$ respectively. Bovine TAP was also active, $\mathrm{LD}_{90}$ proved to be $32 \mu \mathrm{g} / \mathrm{ml}$. All bovine AMPs revealed at least comparable or greater activity at $32 \mu \mathrm{g} / \mathrm{ml}$ against $N$. farcinica than levofloxacin. Accordingly, bovine indolicidin exhibited killing activity against $N$. nova $\left(\mathrm{LD}_{90} 8 \mu \mathrm{g} / \mathrm{ml}\right)$ and $N$. asteroides $\left(\mathrm{LD}_{90} 64 \mu \mathrm{g} / \mathrm{ml}\right)$ (Table 1$)$.

In contrast to human AMPs, bovine indolicidin exhibited activity against $N$. brasiliensis ATCC 19296, thus, representing the sole AMP capable to kill $N$. brasiliensis (Figure $3 \mathrm{~B}$ ). $\mathrm{LD}_{90}$ of indolicidin was $64 \mu \mathrm{g} / \mathrm{ml}$. According to results of hBD-3, N. brasiliensis proved to be resistant to bovine $\beta$-defensins LAP and TAP. Again, pronounced growth was observed after incubation with both AMPs (data not shown).

AMPs are effector molecules of innate immunity and provide a first line of defense against invading pathogens. Our investigations reveal a differential activity of epithelial- and neutrophil-derived AMPs against four members of the genus Nocardia. Whereas N. farcinica and $N$. nova were found to be susceptible to all investigated human and bovine AMPs, $N$. asteroides was killed exclusively by human $\alpha$-defensins HNP 1-3 and bovine indolicidin.

Host-pathogen interactions in Nocardia species have been extensively studied (for review see Beaman et al.) [5]. Severity and manifestations of nocardiosis are influenced by the portal of entry, tissue tropism, inoculum dose and virulence characteristics of the infecting Nocardia strain and, conversely, the efficacy/virtue of the mounted host immune response. Innate defense mechanisms, specifically killing and elimination by neutrophils and macrophages appear to be of particular importance for the outcome of nocardiosis. Although insufficient to resolve infection, the early phagocyte attack is considered to retard infection until lymphocyte-mediated cytotoxicity and activated macrophages accomplish a definite response [16-18].

Table 1 Susceptibility of different Nocardia species against innate defense AMPs

\begin{tabular}{|c|c|c|c|c|c|c|c|}
\hline \multirow[b]{2}{*}{ Species } & \multicolumn{7}{|c|}{$\begin{array}{l}\mathrm{LD}_{90}(\mu \mathrm{g} / \mathrm{ml}) \\
\text { (killing/CFU reduction in percent } \pm \mathrm{SD} \text { ) }\end{array}$} \\
\hline & levoflox & HNP 1-3 & LL-37 & hBD-3 & indolicidin & LAP & TAP \\
\hline N. farcinica ATCC 3318 & $\begin{array}{c}8 \\
(92.3 \pm 3.8)\end{array}$ & $>32$ & $\begin{array}{c}32 \\
(96.6 \pm 0.6)\end{array}$ & $16(92.5 \pm 5.3)$ & $\begin{array}{c}16 \\
(96.7 \pm 1.7)\end{array}$ & $\begin{array}{c}16 \\
(92.9 \pm 7.1)\end{array}$ & $\begin{array}{c}32 \\
(94 \pm 5.1)\end{array}$ \\
\hline N. nova ATCC 33726 & $>32$ & $\begin{array}{c}64 \\
(97.2 \pm 3.6)\end{array}$ & $\begin{array}{c}32 \\
(91.4 \pm 7.0)\end{array}$ & $\begin{array}{c}16 \\
(95.2 \pm 1.7)\end{array}$ & $\begin{array}{c}8 \\
(90.5 \pm 3.4)\end{array}$ & n.d. & n.d. \\
\hline N. asteroides ATCC 19247 & $\begin{array}{c}8 \\
(92.6 \pm 3.8)\end{array}$ & $\begin{array}{c}32 \\
(90.9 \pm 0.6)\end{array}$ & $>64$ & $>64$ & $\begin{array}{c}64 \\
(99.1 \pm 0.6)\end{array}$ & n.d. & n.d. \\
\hline N. brasiliensis ATCC 19296 & $\begin{array}{c}32 \\
(96.6 \pm 2.2)\end{array}$ & $>64$ & $>64$ & $>64$ & $\begin{array}{c}64 \\
(92.9 \pm 2.1)\end{array}$ & $>64$ & $>64$ \\
\hline
\end{tabular}

$\mathrm{LD}_{90}$ denotes the lowest peptide concentration leading to $\mathrm{a}=90 \%$ reduction of CFU after incubation (12 $\mathrm{h}$ or $16 \mathrm{~h}$ ) with AMPs or levofloxacin. Presented data are $\mathrm{LD}_{90}$ determinations based on means of at least four (levofloxacin, HNP 1-3, LL-37 and hBD-3) or two (indolicidin, LAP and TAP) independent sets of experiments with each Nocardia species. In brackets are means (percent CFU reduction) \pm standard deviation of respective experiments.

SD standard deviation, n.d. not determined 

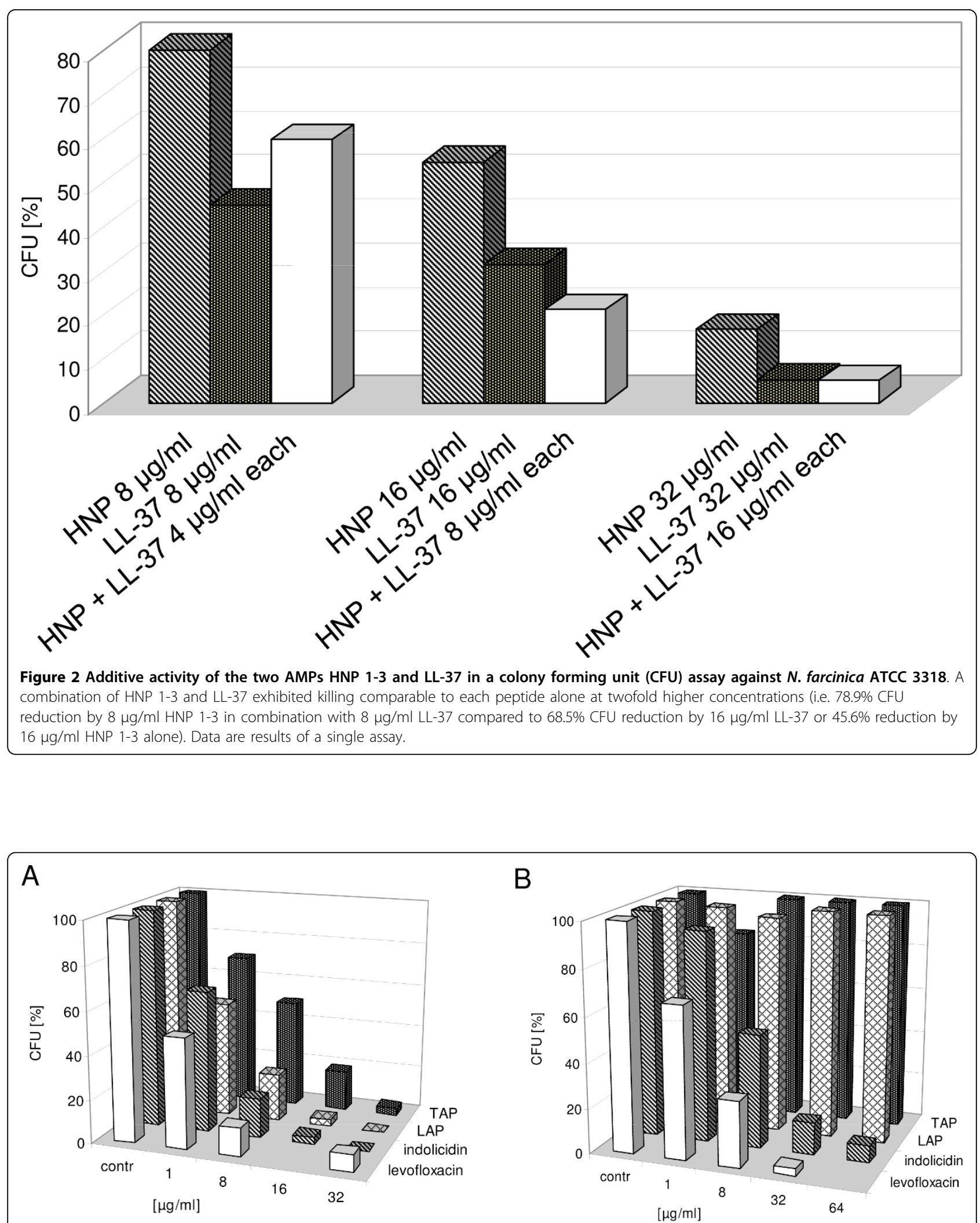

Figure 3 Activity of bovine AMPs TAP, LAP indolicidin and levofloxacin (killing control) against A $\mathbf{N}$. farcinca ATCC 3318 ( $p<0.05$ for all tested substances), B N. brasiliensis ATCC 19296 (indolicidin and levofloxacin $p<0.05$ ) was investigated using a colony forming unit (CFU) assay. Data are means (percent CFU reduction) of at least two independent sets of experiments with each peptide and each Nocardia species. 
Constituting a major part of the microbicidal mechanisms of neutrophils, we propose AMPs to contribute to the early phase of defense against various Nocardia species. Interestingly and in favour of our hypothesis, we found neutrophil-derived AMPs such as human HNP 13 and bovine indolicidin to have broader antinocardial activity than the investigated epithelial AMP hBD-3 (albeit in equimolar concentrations hBD-3 exhibited greater CFU reduction/killing of $N$. farcinica and $N$. nova than HNP1-3). Moreover, besides their abundant presence in neutrophils, AMPs are produced by other innate defense effector cells. LL-37 and, to a lesser extent, HNP 1-3 were found in monocytes/macrophages, NK cells and $\gamma \delta$ T cells [19], which are also considered to take part in antinocardial defense.

Several virulence determinants of Nocardia including lysozyme resistance and inhibition of phagosome-lysosome fusion have been described [20]. Due to prior investigations, host-pathogen interactions are best charaterized in $N$. asteroides infection. A distinct feature of virulent strains of $N$. asteroides is the capability to resist to oxidative burst-mediated killing by phagocytes due to catalase [21] and superoxide dismutase production [22]. Here we found HNP 1-3 and indolicidin to represent nocardicidal effector molecules belonging to the armament of non-oxidative killing mechanisms of neutrophils. In accordance with our observations, Filice et al. found neutrophil granule-derived cationic proteins (containing HNP 1-3) to inhibit $N$. asteroides growth and filament formation [23].

In human neutrophils, $\alpha$-defensins HNP 1-3 are stored as active peptides in primary (azurophil) granules in concentrations of $>10 \mathrm{mg} / \mathrm{ml}$ [24]. As granulecontents are minimally diluted after fusion with the phagocytic vacuole, HNP 1-3 targets ingested pathogens in concentrations multitudes higher than those needed for potent antinocardial killing observed in our study $\left(\mathrm{LD}_{90}\right.$ of $N$. farcinca, $N$. nova and $N$. asteroides $=$ $64 \mu \mathrm{g} / \mathrm{ml}$ ). In contrast, the human cathelicidin is stored as inactive precursor hCAP-18 in secondary (specific) granules and is processed to LL-37 by proteinase 3 after secretion into the extracellular milieu. Like the human $\beta$-defensin hBD-3, LL-37 is additionally produced upon infection or inflammation by epithelial cells of the respiratory/gastrointestinal tract or by keratinocytes. Levels of LL-37 e.g. in airway surface fluids are estimated to be $1-5 \mu \mathrm{g} / \mathrm{ml}$ [25]. Concentrations of $\beta$-defensins are estimated to be in the range of 1-10 $\mu \mathrm{g} / \mathrm{ml}$ [13]. Thus, in vivo concentrations of LL-37 and hBD-3 will most likely be not sufficient to exert direct nocardial killing. Nevertheless, LL-37 and hBD-3 may take part in antinocardial defense by additive or synergistic action with other antimicrobial peptides and proteins abundantly present along epithelial barriers. In favour of this hypothesis, we found additive killing of $N$. farcinica in a model assay using a combination of LL-37 and HNP 1-3. Moreover, owing to a wide range of biological activities, LL-37 and hBD-3 may further contribute due to chemotactic effects on neutrophils, monocytes and T cells [26,27].

We found N. brasiliensis to exhibit complete resistance to all investigated human AMPs and to be susceptible only to bovine indolicidin. $N$. brasiliensis is the most frequently reported cause of progressive cutaneous and lymphocutaneous disease. Furthermore, N. brasiliensis often causes infection in otherwise immunocompetent hosts. These clinical features are in accordance with our findings, demonstrating a complete resistance of $N$. brasiliensis against human epithelial, i.e. keratinocyte-derived and neutrophil-derived AMPs.

$N$. brasiliensis is known to produce a variety of proteases [28]. To evaluate a potential resistance due to proteolytic degradation of AMPs (particularly linear $\alpha$-helical LL-37), CFU-assays were conducted in the presence of protease inhibitors. However, protease inhibitors did not alter AMP-resistance in N. brasiliensis. One might speculate about species-specific variances in bacterial cell wall constituents yielding to differential nocardial AMP susceptibility/resistance [29]. Additionally, other mechanisms, i.e. active efflux by multi-drug transporters or modifications on the bacterial cell surface may confer AMP resistance.

The current study revealed $N$. brasiliensis to be susceptible only to indolicidin, a tryptophan- and prolinerich 13 amino acid peptide of bovine neutrophils. In contrast to the predominantly membrane-active human defensins and cathelicidin LL-37, indolicidin has been referred to exert intracellular modes of action with inhibition of DNA and protein-synthesis and alteration of cytoplasmic membrane septum formation [30]. Thus, its distinct chemical features and alternative mode of action may contribute to the unique activity of indolicidin against $N$. brasiliensis.

\section{Conclusions}

Selected AMPs are capable to contribute to the first line of defense against Nocardia, yet, susceptibility appears to vary across different Nocardia species. Interestingly, our finding of neutrophil-derived AMPs to possess a broad antinocardial spectrum is paralleled by the characteristic feature of a neutrophil-rich infiltrate in histopathological specimens of nocardiosis. Moreover, the observed resistance of $N$. brasiliensis is remarkable, since $N$. brasiliensis is frequently reported to cause cutaneous and lymphocutaneous disease in otherwise immunocompetent hosts. Further studies should address in more detail the differential activity of AMPs, its causes and pathophysiologic significance. 


\section{Methods}

\section{Bacterial strains and culture conditions}

Four strains of the genus Nocardia were investigated: Nocardia farcinica (ATCC 3318), Nocardia nova (ATCC 33726), Nocardia asteroides (ATCC 19247) and Nocardia brasiliensis (ATCC 19296). Strains were grown on Columbia blood agar for at least 72 hours at $37^{\circ} \mathrm{C}$. Then $30 \mathrm{ml}$ of Mueller-Hinton-broth (MHB) supplemented with 1\% Tween 80 (Serva, Heidelberg, Germany) was inoculated with one loop of bacteria scraped off the agar plates. MHB was incubated in a shake incubator $\left(220 \mathrm{rpm}\right.$ at $\left.37^{\circ} \mathrm{C}\right) .10 \mathrm{ml}$ of the culture was transferred to a $50 \mathrm{ml}$ tube which contained $1 \mathrm{~mm}$ glass beads (BioSpec Products, Bartlesville, USA). After vortexing for 10-15 seconds a homogenous suspension could be gained. A few millilitres of the suspension were used to inoculate another $50 \mathrm{ml}$ of MHB (also supplemented with $1 \%$ Tween 80 ). Cultures were incubated until mid-logarithmic phase was reached. Incubation times were different for each Nocardia species ( $N$. farcinica $12 \mathrm{~h}, N$. nova $24 \mathrm{~h}, N$. asteroides $16 \mathrm{~h}, N$. brasiliensis $72 \mathrm{~h})$.

\section{Innate defense antimicrobial peptides}

The activities of major human and bovine AMPs belonging to different families of AMPs were tested (summarized in Table 2): human cathelicidin LL-37, human $\alpha$-defensins human neutrophil peptides 1-3 (HNP 1-3) and human $\beta$-defensin-3 (hBD-3), bovine indolicidin and bovine $\beta$-defensins lingual antimicrobial peptide (LAP) and tracheal antimicrobial peptide (TAP). Human cathelicidin LL-37, bovine indolicidin, LAP and TAP were synthesized using standard Fmoc/tBu chemistry on a multiple peptide synthesizer Syro II (MultiSynTech, Witten, Germany). Oxidation of the reduced LAP and TAP was achieved by dissolving the prepurified peptide with $2 \mathrm{M}$ acetic acid and dilution to a peptide concentration of $0.015 \mathrm{mM}$ in the presence of reduced/ oxidized glutathione (molar ratio of peptide/GSH/GSSG was 1:100:10) and $2 \mathrm{M}$ guanidine hydrochloride. The solution was adjusted to $\mathrm{pH} 8.0$ with aqueous $\mathrm{NH}_{4} \mathrm{OH}$ and stirred slowly at $4^{\circ} \mathrm{C}$ for 3 days. The folding reaction was monitored by analytical HPLC. The solution was concentrated using a C18 Sep-Pak cartridge (Waters, Milford, USA) and lyophilized. Purification of the oxidized products was achieved first by chromatography on a C8 column using the system above and yielding a purity of $90 \%$. Finally, the product was highly purified on a C18 column using a 60 min gradient resulting in a purity of $95 \%$. The quality of the product was confirmed by analytical HPLC, matrix-assisted laser desorption/ionization time of flight mass spectrometry (MALDI-MS), and electrospray ionization mass spectrometry (ESI-MS), yielding the correct mass of oxidized products. Human $\alpha$-defensins HNP 1-3 were isolated from peripheral neutrophils as previously described [31]. Synthetic hBD-3 was purchased from PeptaNova, Sandhausen, Germany.

Levofloxacin (Roussel-Uclaf, Romainville, France) was used as killing control and dissolved in water. A 30 amino acid peptide named DPY without antimicrobial activity was used as negative control [32]. DPY was synthesized using standard F-moc/tBu chemistry and purified by HPLC according to the protocol used for HNP 1-3. All peptides were dissolved in $0.01 \%$ acetic acid. Antimicrobial agents were stored at $-20^{\circ} \mathrm{C}$ and were defreezed and freezed three times at a maximum to ensure full antimicrobial activity.

\section{Colony forming unit assay}

A colony forming unit (CFU) assay was established and performed to test AMP susceptibility. Mid-logarithmic growth phase cultures were washed twice in $10 \mathrm{mM}$ sodium phosphate buffer (ph 7.4). A standard inoculum of $1 \times 10^{7} \mathrm{CFU} / \mathrm{ml}$ in $10 \mathrm{mM}$ sodium phosphate buffer supplemented with $1 \% \mathrm{MHB}$ was prepared. $80 \mu \mathrm{l}$ of the standard inoculum were incubated with $20 \mu$ of the respective concentrations of the antimicrobial agents in the shake incubator at $37^{\circ} \mathrm{C}$ for $12 \mathrm{~h}$ ( N. farcinica) to $16 \mathrm{~h}$ ( N. nova, $N$. asteroides and $N$. brasiliensis). Incubation was carried out in $2 \mathrm{ml}$ tubes (Eppendorf, Hamburg, Germany) which were occluded by LidBacs (Eppendorf, Hamburg, Germany) to avoid contamination and provide constant aerobic conditions. After

Table 2 Features of human AMPs used in this study

\begin{tabular}{|c|c|c|c|}
\hline AMP & class/structure & origin & expression pattern \\
\hline LL-37 & cathelicidin, $\alpha$-helical peptide & human & $\begin{array}{c}\text { neutrophils, monocytes/macrophages (constitutive); epithelial cells of respiratory, gastrointestinal } \\
\text { and urogenital tract, keratinocytes (inducible) }\end{array}$ \\
\hline HNP 1-3 & $\alpha$-defensins, $\beta$-sheet peptides & human & neutrophils (constitutive) \\
\hline hBD-3 & $\beta$-defensin, $\beta$-sheet peptide & human & epithelial cells of respiratory and gastrointestinal tract, keratinocytes (inducible) \\
\hline indolicidin & $\begin{array}{l}\text { linear, tryptophan- and } \\
\text { proline-rich peptide }\end{array}$ & bovine & neutrophils (constitutive) \\
\hline LAP & $\beta$-defensin, $\beta$-sheet peptide & bovine & epithelial cells of respiratory and gastrointestinal tract, mammary gland (inducible) \\
\hline TAP & $\beta$-defensin, $\beta$-sheet peptide & bovine & epithelial cells of respiratory tract (inducible) \\
\hline
\end{tabular}


incubation serial dilutions were plated on Mueller-Hinton agar plates and visible colonies were counted after 48-72 hours of incubation at $37^{\circ} \mathrm{C}$. Killing was expressed in percentage of bacteria that were killed by incubation with respective peptide concentrations compared to incubation with solvent of the antibacterial substance $\left(0,01 \%\right.$ acetic acid or water). $\mathrm{LD}_{90}$ denotes the lowest peptide concentration leading to $a=90 \%$ reduction of CFU counts. CFU assays were at least performed three times and final results are displayed as mean value of all assays. Killing activity (CFU counts after incubation with solvent vs. CFU counts after incubation with highest concentration of AMPs or levofloxacin) was analysed by Student's t-test. A p-value $<0.05$ was considered significant.

For testing $N$. brasiliensis, CFU assays were additionally performed by adding a protease inhibitor mix (Complete Mini, Roche, Mannheim, Germany). $10 \mu \mathrm{l}$ of the protease inhibitor mix were added to the standard inoculum during the $16 \mathrm{~h}$ incubation period. Further testing was performed as described above.

\section{Acknowledgements}

This study was supported in part by research grant RIE520/06 of the Medical Faculty of Freiburg University, Germany.

\section{Author details}

${ }^{1}$ Center for Infectious Diseases \& Travel Medicine, University Medical Center, Hugstetter Strasse 55, 79106 Freiburg, Germany. ${ }^{2}$ Medical and Natural Sciences Research Center, University of Tübingen, Ob dem Himmelreich 7, 72074 Tübingen, Germany.

\section{Authors' contributions}

SR conceived of the study, drafted and wrote the manuscript and participated in experiments. BM performed antimicrobial assays and helped to draft the manuscript. EF performed antimicrobial assays. AH performed antimicrobial assays. DW participated in the design of the study and analysis of its results. WVK conceived of the study, participated in its design and coordination and edited the manuscript. HK synthesised antimicrobial peptides and helped to draft and edit the manuscript. All authors have read and approved the final manuscript.

Received: 4 May 2009

Accepted: 23 February 2010 Published: 23 February 2010

\section{References}

1. Saubolle MA, Sussland D: Nocardiosis: review of clinical and laboratory experience. J Clin Microbiol 2003, 41:4497-4501.

2. Roth A, Andrees S, Kroppenstedt RM, Harmsen D, Mauch H: Phylogeny of the genus Nocardia based on reassessed 16S rRNA gene sequences reveals underspeciation and division of strains classified as Nocardia asteroides into three established species and two unnamed taxons. $J$ Clin Microbiol 2003, 41:851-856.

3. Wellinghausen N, Pietzcker T, Kern WV, Essig A, Marre R: Expanded spectrum of Nocardia species causing clinical nocardiosis detected by molecular methods. Int I Med Microbiol 2002, 292:277-282.

4. Brown-Elliott BA, Brown JM, Conville PS, Wallace RJ Jr: Clinical and laboratory features of the Nocardia spp. based on current molecular taxonomy. Clin Microbiol Rev 2006, 19:259-282.

5. Beaman BL, Beaman L: Nocardia species: host-parasite relationships. Clin Microbiol Rev 1994, 7:213-264
6. Harder J, Bartels J, Christophers E, Schroder JM: Isolation and characterization of human beta -defensin-3, a novel human inducible peptide antibiotic. J Biol Chem 2001, 276:5707-5713.

7. Schonwetter BS, Stolzenberg ED, Zasloff MA: Epithelial antibiotics induced at sites of inflammation. Science 1995, 267:1645-1648.

8. Diamond G, Zasloff M, Eck H, Brasseur M, Maloy WL, Bevins CL: Tracheal antimicrobial peptide, a cysteine-rich peptide from mammalian tracheal mucosa: peptide isolation and cloning of a cDNA. Proc Natl Acad Sci USA 1991, 88:3952-3956.

9. Ganz T, Selsted ME, Szklarek D, Harwig SS, Daher K, Bainton DF, et al: Defensins. Natural peptide antibiotics of human neutrophils. J Clin Invest 1985, 76:1427-1435.

10. Selsted ME, Novotny MJ, Morris WL, Tang YQ, Smith W, Cullor JS: Indolicidin, a novel bactericidal tridecapeptide amide from neutrophils. J Biol Chem 1992, 267:4292-4295

11. Lehrer Rl, Ganz T: Cathelicidins: a family of endogenous antimicrobial peptides. Curr Opin Hematol 2002, 9:18-22.

12. Zasloff M: Antimicrobial peptides of multicellular organisms. Nature 2002, 415:389-395

13. Hancock RE: Cationic peptides: effectors in innate immunity and novel antimicrobials. Lancet Infect Dis 2001, 1:156-164.

14. Martineau AR, Newton SM, Wilkinson KA, Kampmann B, Hall BM, Nawroly N, et al: Neutrophil-mediated innate immune resistance to mycobacteria. J Clin Invest 2007, 117:1988-1994

15. Joly S, Maze C, McCray PB Jr, Guthmiller JM: Human beta-defensins 2 and 3 demonstrate strain-selective activity against oral microorganisms. J Clin Microbiol 2004, 42:1024-1029.

16. Deem RL, Doughty FA, Beaman BL: Immunologically specific direct $T$ lymphocyte-mediated killing of Nocardia asteroides. J Immunol 1983, 130:2401-2406.

17. Deem RL, Beaman BL, Gershwin ME: Adoptive transfer of immunity to Nocardia asteroides in nude mice. Infect Immun 1982, 38:914-920.

18. Filice GA, Niewoehner DE: Contribution of neutrophils and cell-mediated immunity to control of Nocardia asteroides in murine lungs. $J$ Infect Dis 1987, 156:113-121.

19. Agerberth B, Charo J, Werr J, Olsson B, Idali F, Lindbom L, et al: The human antimicrobial and chemotactic peptides LL-37 and alpha-defensins are expressed by specific lymphocyte and monocyte populations. Blood 2000, 96:3086-3093.

20. Davis-Scibienski C, Beaman BL: Interaction of Nocardia asteroides with rabbit alveolar macrophages: association of virulence, viability, ultrastructural damage, and phagosome-lysosome fusion. Infect Immun 1980, 28:610-619.

21. Filice GA, Beaman BL, Krick JA, Remington JS: Effects of human neutrophils and monocytes on Nocardia asteroides: failure of killing despite occurrence of the oxidative metabolic burst. J Infect Dis 1980, 142:432-438

22. Beaman BL, Black CM, Doughty F, Beaman L: Role of superoxide dismutase and catalase as determinants of pathogenicity of Nocardia asteroides: importance in resistance to microbicidal activities of human polymorphonuclear neutrophils. Infect Immun 1985, 47:135-141.

23. Filice GA: Inhibition of Nocardia asteroides by neutrophils. J Infect Dis 1985, 151:47-56

24. Ganz T: Extracellular release of antimicrobial defensins by human polymorphonuclear leukocytes. Infect Immun 1987, 55:568-571.

25. Bals R, Wilson JM: Cathelicidins-a family of multifunctional antimicrobial peptides. Cell Mol Life Sci 2003, 60:711-720.

26. De Y, Chen Q, Schmidt AP, Anderson GM, Wang JM, Wooters J, et al: LL-37, the neutrophil granule- and epithelial cell-derived cathelicidin, utilizes formyl peptide receptor-like 1 (FPRL1) as a receptor to chemoattract human peripheral blood neutrophils, monocytes, and T cells. J Exp Med 2000, 192:1069-1074.

27. Funderburg N, Lederman MM, Feng Z, Drage MG, Jadlowsky J, Harding CV, et al: Human -defensin-3 activates professional antigen-presenting cells via Toll-like receptors 1 and 2. Proc Natl Acad Sci USA 2007, 104:18631-18635.

28. Zlotnik H, Schramm VL, Buckley HR: Purification and partial characterization of a Nocardia brasiliensis extracellular protease. $J$ Bacteriol 1984, 157:627-631. 
29. Beadles TA, Land GA, Knezek DJ: An ultrastructural comparison of the cell envelopes of selected strains of Nocardia asteroides and Nocardia brasiliensis. Mycopathologia 1980, 70:25-32.

30. Subbalakshmi C, Sitaram N: Mechanism of antimicrobial action of indolicidin. FEMS Microbiol Lett 1998, 160:91-96.

31. Weidenmaier C, Kokai-Kun JF, Kristian SA, Chanturiya T, Kalbacher $H$, Gross $\mathrm{M}$, et al: Role of teichoic acids in Staphylococcus aureus nasal colonization, a major risk factor in nosocomial infections. Nat Med 2004, 10:243-245.

32. Steffen H, Rieg S, Wiedemann I, Kalbacher H, Deeg M, Sahl HG, et al: Naturally processed dermcidin-derived peptides do not permeabilize bacterial membranes and kill microorganisms irrespective of their charge. Antimicrob Agents Chemother 2006, 50:2608-2620.

doi:10.1186/1471-2180-10-61

Cite this article as: Rieg et al:: Differential activity of innate defense antimicrobial peptides against Nocardia species. BMC Microbiology 2010 10:61.

\section{Submit your next manuscript to BioMed Central} and take full advantage of:

- Convenient online submission

- Thorough peer review

- No space constraints or color figure charges

- Immediate publication on acceptance

- Inclusion in PubMed, CAS, Scopus and Google Scholar

- Research which is freely available for redistribution

Submit your manuscript at www.biomedcentral.com/submit 